\title{
PENGARUH PENERAPAN MODEL PEMBELAJARAN KOOPERATIF TIPE THINK PAIR SHARE TERHADAP HASIL BELAJAR MATEMATIKA SISWA KELAS VIII SMP NEGERI 8 KENDARI
}

\author{
Rahmawati $^{(1)}$ Suhar ${ }^{2)}$, La Masi $^{3)}$ \\ ${ }^{1)}$ Alumni Jurusan Pendidikan Matematika, ${ }^{2,3)}$ Dosen Jurusan Pendidikan Matematika FKIP \\ Universitas Halu Oleo Email : ayurahmawatiayu2593@gmail.com
}

\begin{abstract}
Abstrak
Penelitian ini bertujuan untuk mengetahui: (1) pelaksanaan model pembelajaran kooperatif tipe TPS, (2) hasil belajar matematika siswa yang diajar dengan menggunakan model pembelajaran kooperatif tipe TPS, (3) hasil belajar matematika siswa yang diajar dengan menggunakan model pembelajaran konvensional, (4) pengaruh penerapan model pembelajaran kooperatif tipe TPS terhadap peningkatan hasil belajar matematika siswa. Populasi dalam penelitian ini adalah siswa kelas VIII SMPN 8 Kendari yang tersebar di 7 kelas paralel dengan guru yang berbeda. Teknik pengambilan sampel dalam penelitian dilakukan secara purposive sampling. Berdasarkan hasil analisis data dan pembahasan diperoleh kesimpulan. (1) tingkat keterlaksanaan proses pembelajaran kooperatif tipe TPS selama 5 kali pertemuan secara keseluruhan tingkat ketercapaian keterlaksanaan pembelajaran oleh guru sudah tergolong baik. (2) rata-rata hasil belajar siswa yang diajar dengan model pembelajaran kooperatif tipe TPS sebesar 54.61. (3) rata-rata hasil belajar matematika siswa yang diajar dengan model pembelajaran konvensional sebesar 31.80.
\end{abstract}

Kata Kunci: hasil belajar matematika, pembelajaran konvensional, proses pembelajaran

\section{THE INFLUENCE OF THE APPLICATION OF COOPERATIVE LEARNING MODEL TYPE THINK PAIR SHARE (TPS) ON THE RESULT OF LEARNING MATHEMATICS STUDENTS OF CLASS VIII SMP NEGERI 8 KENDARI}

\begin{abstract}
This study aims to determine: (1) implementation of cooperative learning model of TPS type, (2) mathematics learning result of students taught by using cooperative learning model of TPS type, (3) mathematics learning result of students taught by using conventional learning model, (4) influence of application of cooperative learning model of TPS type to increase result of learning mathematics of student. The population in this study were students of class VIII SMPN 8 Kendari which was spread in parallel classes with different teachers. Sampling technique in research conducted by purposive sampling. Based on data analysis and discussion obtained conclusion. (1) the level of implementation of cooperative of TPS type during the 5 meetings as a whole the level of achievement of learning implementation by teachers has been classified as good. (2) the average of student learning outcomes taught with cooperative type model of TPS type is 54.61. (3) the average of students' mathematics learning outcomes taught by conventional learning model is 31.80 .
\end{abstract}

Keywords: Students' Mathematics Learning Outcomes, learning process, conventional learning 


\section{Pendahuluan}

Matematika adalah salah satu mata pelajaran yang mempunyai pengaruh yang sangat penting karena hampir semua ilmu pengetahuan ada unsur matematika. Matematika bukan hanya berupa simbol, tetapi juga melatih berpikir siswa. Kline dalam Abdul Rahman (1999:252) mengemukakan bahwa matematika merupakan bahasa simbolis dan ciri utamanya adalah penggunaan cara bernalar deduktif tetapi juga tidak melupakan cara bernalar induktif.

Pembelajaran di sekolah adalah proses pembelajaran yang sifatnya kompleks dan menyeluruh. Banyak orang yang berpendapat bahwa untuk meraih prestasi yang tinggi dalam belajar, seseorang harus memiliki Intelligence Quotient (IQ) yang tinggi, karena inteligensi merupakan bekal potensial yang akan memudahkan dalam belajar dan pada gilirannya akan menghasilkan prestasi belajar yang optimal.

Kemampuan hasil belajar matematika siswa merupakan bagian dari hasil belajar. Dimana hasil belajar adalah kemampuan yang diperoleh oleh individu setelah pembelajaran berlangsung, yang dapat memberikan perubahan tingkah laku baik pengetahuan, keterampilan, dan sikap peserta didik sehingga lebih baik dari sebelumnya. Hasil belajar merupakan hasil dari suatu interaksi tindak belajar dan tindak mengajar. Dari sisi guru, tindak mengajar merupakan berakhirnya proses evaluasi hasil belajar dan sisi siswa, hasil belajar merupakan berakhirnya pengalaman dan puncak proses belajar.

Rendahnya kemampuan hasil belajar matematika siswa di SMPN 8 Kendari salah satu faktor penyebabnya, berkaitan dengan pembelajaran yang diselenggarakan guru di sekolah. Selama ini guru cenderung text book oriented (berorientasi buku teks) dan masih didominasi dengan pembelajaran yang terpusat pada guru. Kebanyakan guru dalam mengajar masih kurang memperhatikan kemampuan berpikir siswa atau tidak mempertimbangkan tingkat kognitif siswa sesuai dengan perkembangan usianya.

Pemilihan strategi dan metode pembelajaran yang tepat akan meningkatkan kreativitas siswa untuk semangat dalam belajar (Roida dan Maya, 2012: 39). Demikian halnya dengan kemampuan dan hasil belajar siswa juga memerlukan sebuah metode pembelajaran yang mempunyai karakteristik membangun kategori, menentukan masalah dan menciptakan lingkungan yang mendukung. Model pembelajaran yang dimaksud tersebut adalah model pembelajaran kooperatif tipe Think Pair Share (TPS).

Model pembelajaran kooperatif merupakan salah satu solusi untuk memperbaiki dan meningkatkan kualitas dan proses pembelajaran pada umumnya dan pembelajaran matematika pada khususnya. Pembelajaran kooperatif memiliki ciri khusus yakni pembelajaran yang berpusat pada siswa dibandingkan dengan pembelajaran lainnya yang berpusat pada guru (Maonde, 2014: 3).

TPS menurut Nurhadi dkk (2004: 66) memiliki prosedur yang ditetapkan secara tegas (eksplisit) untuk memberi siswa waktu lebih banyak untuk berpikir, menjawab, dan saling membantu. Setelah guru menyajikan suatu topik atau setelah siswa membaca suatu tugas, selanjutnya guru meminta siswa untuk memikirkan permasalahan yang ada dalam topik/bacaan tersebut. Dalam model ini siswa untuk memikirkan suatu topik, berpasangan dengan siswa lain dan mendiskusikannya, kemudian berbagi ide dengan seluruh kelas.

TPS digunakan untuk mengajarkan isi akademik atau untuk mengecek pemahaman siswa terhadap isi tertentu. Guru menciptakan interaksi yang dapat mendorong rasa ingin tahu, ingin mencoba, bersikap mandiri, dan ingin maju. Guru memberi informasi, hanya informasi yang mendasar saja, sebagai dasar pijakan bagi anak didik dalam mencari dan menemukan sendiri informasi lainnya. Atau guru menjelaskan materi dengan mengaitkannya dengan pengalaman dan pengetahuan anak sehingga memudahkan mereka menanggapi dan memahami pengalaman yang baru bahkan membuat anak didik mudah memusatkan perhatian. Karenanya guru sangat perlu memperhatikan pengalaman dan pengetahuan anak didik yang didapatinya dalam kehidupan sehari-hari.

Belajar dalam kamus besar bahasa Indonesia berarti berusaha mengetahui sesuatu, berusaha memperoleh ilmu pengetahuan (kepandaian, keterampilan) (Tim Penyusun Kamus Pusat Bahasa, 2008: 24), sedangkan menurut pandangan psikologi, belajar adalah proses perubahan tingkah laku sebagai akibat dari pengalaman dan latihan. Perubahan tingkah 
laku akibat belajar itu dapat berupa memperoleh perilaku yang baru atau memperbaiki/meningkatkan perilaku yang sudah ada. Perubahan tingkah laku yang ditimbulkan oleh belajar dapat berupa perilaku yang baik (positif) atau perilaku yang buruk (negatif) (Sabri, 1996: 35)

Menurut Hilgard (Mudjijana, 2002), belajar merupakan proses yang aktif untuk membangun pengetahuan dan keterampilan siswa. Depdiknas (Mudjijana, 2002) menyatakan belajar sebagai kegiatan yang menghasilkan 15 perubahan tingkah laku pada diri individu yang sedang belajar, baik potensial maupun aktual. Pada intinya belajar memiliki hal-hal pokok sebagai berikut:

a. Belajar membawa perubahan perilaku baik aktual maupun potensial.

b. Perubahan didapat dengan peningkatan kecakapan.

c. Perubahanterjadi karena siswa aktif melakukan aktivitas untukmembangun sendiri pengetahuannya.

Beberapa pengertian belajar yang dikemukakan oleh para ahli, maka penulis menyimpulkan bahwa belajar adalah perubahan (baik positif maupun negatif) yang lahir dari serangkaian proses, kegiatan atau pengalaman yang dialami seseorang berupa pengetahuan atau sikap terhadap dirinya sendiri dan lingkungannya.

Usman (dalam Jihad, 2008: 12) mengemukakan pembelajaran adalah inti dari proses pendidikan secara keseluruhan dengan guru sebagai pemegang peranan utama. Pembelajaran merupakan suatu proses yang mengandung serangkaian perbuatan guru dan siswa atas dasar hubungan timbal balik yang berlangsung dalam situasi edukatif untuk mencapai tujuan tertentu. Sedangkan Suherman (dalam Jihad, 2008: 11) mengemukakan bahwa pembelajaran merupakan suatu proses yang terdiri dari kombinasi dua aspek, yaitu: belajar tertuju kepada apa yang harus dilakukan oleh siswa, mengajar berorientasi pada apa yang harus dilakukan oleh guru sebagai pemberi pelajaran. Kedua aspek ini akan berkalaborasi secara terpadu menjadi suatu kegiatan pada saat terjadi interaksi antara guru dengan siswa, serta antara siswa dengan siswa disaat pembelajaran sedang berlangsung. Dengan kata lain, pembelajaran pada hakikatnya merupakan proses komunikasi antara peserta didik dengan pendidik serta antar peserta didik dalam rangka perubahan sikap.

Mustafa (Tri Wijayanti, 2011) menyebutkan bahwa matematika adalah ilmu tentang kuantitas, bentuk, susunan, dan ukuran, yang utama adalah metode dan proses untuk menemukan dengan konsep yang tepat dan lambang yang konsisten, sifat dan hubungan antara jumlah dan ukuran, baik secara abstrak, matematika murni atau dalam keterkaitan manfaat pada matematika terapan.

Menurut Bloom dalam Sudjana (1989: 22) mengemukakan hasil belajar adalah kemampuan-kemampuan yang dimiliki siswa setelah ia menerima pengalaman belajarnya. Horward Kingsley membagi tiga macam hasil belajar, (a) keterampilan dan kebiasan, (b) pengetahuan dan pengertian, (c) dan sikap dan cita-cita. Masing-masing jenis hasil belajar dapat diisi dengan bahan yang telah ditetapkan dalam kurikulum. Sedangkan Gagne membagi lima kategori hasil belajar, yakni (a) informasi verbal, (b) keterampilan intelektual, (c) strategi kognitif, (d) sikap dan keterampilan motoris.

Ibrahim (2000: 6) pembelajaran yang menggunakan pendekatan kooperatif memiliki karakteristik sebagai berikut: 1) Siswa bekerja dalam kelompok secara kooperatif untuk meuntaskan materi belajarnya; 2) Kelompok dibentuk dari siswa yang memiliki kemampuan tinggi, sedang dan rendah; 3) Bilamana mungkin anggota kelompok berasal dari ras, budaya, suku, jenis kelamin berbeda-beda; dan 4) Penghargaan lebih berorientasi pada kelompok ketimbang individu.

Selanjutnya Lie (2002: 30) mengatakan bahwa pendekatan pembelajaran kooperatif dimunculkan dalam 5 unsur dimana setiap siswa harus: 1) Adanya saling ketergantungan positif antara anggota kelompok, 2) Adanya tanggung jawab perseorangan. Artinya, setiap anggota kelompok harus melaksanakan tugasnya dengan baik untuk keberhasilan tugas kelompok, 3) Adanya tatap muka, setiap kelompok harus diberikan kesempatan untuk bertatap muka dan berdiskusi, 4) Harus ada komunikasi antar anggota. Dalam hal ini siswa tentu harus dibekali dengan teknik berkomunikasi, 5) Adanya evaluasi proses kelompok, yang dijadwalkan dan dilaksanakan oleh guru.

Model pembelajaran kooperatif tipe Think Pair Share (TPS) merupakan tipe yang sederhana dengan banyak keuntungan karena dapat meningkatkan partisipasi siswa dan 
pembentukan pengetahuan oleh siswa. Dengan menggunakan suatu prosedur, para siswa belajar dari siswa yang lain dan berusaha untuk mengeluarkan pendapatnya dalam situasi non kompetisi sebelum mengungkapkannya di depan kelas.

Juliantara (2011: 1) pembelajaran konvensional (tradisional) merupakan pengemasan belajar dan pembelajaran yang ditandai dengan aktivitas guru menyimpan dan memberi informasi dalam pikiran siswa yang pasif dan dianggap kosong. Siswa hanya menerima informasi verbal dari guru-guru atau ahli. Proses ini lebih jauh akan berimplikasi pada terjadinya hubungan yang bersifat antagonisme diantara guru dan siswa. Guru sebagai subjek yang aktif dan siswa sebagai objek yang pasif dan diperlakukan tidak menjadi bagian dari realita dunia yang diajarkan kepada mereka. Pembelajaran konvensional menekankan pada resitasi konten, tanpa memberikan waktu yang cukup kepada siswa untuk merefleksi materi-materi yang dipresentasikan, menghubungkan dengan pengetahuan sebelumnya, atau mengaplikasikannya kepada situasi kehidupan nyata. Lebih lanjut dinyatakan bahwa pembelajaran konvensional memiliki cirri-ciri, yaitu: (1) pembelajaran berpusat pada guru, (2) terjadi passive learning, (3) interaksi diantara siswa kurang, (4) tidak ada kelompok-kelompok kooperatif, dan (5) penilian bersifat sporadis.

\section{Metode}

Jenis penelitian yang digunakan dalam penelitian ini adalah eksperimen dengan menggunakan pendekatan Model Pembelajaran Kooperatif Tipe Think Pair Share (TPS) sebagai kelas eksperimen dan pembelajaran konvensional sebagai kelas kontrol. Populasi dalam penelitian ini adalah seluruh siswa kelas VIII SMPN 8 Kendari yang terdaftar pada tahun ajaran 2016/2017 yang tersebar dalam 7 kelas paralel. Pengambilan sampel pada penelitian ini dilakukan dengan menggunakan teknik purposive sampling, karena penyebaran kemampuan siswa di tiap kelas relatif sama. Dari cara tersebut diperoleh kelas $\mathrm{VIII}_{3}$ dan kelas $\mathrm{VIII}_{4}$. Penentuan kelas yang akan diajar dengan model pembelajaran kooperatif tipe TPS dan pembelajaran konvensional juga dilakukan secara purposive sampling, dalam penentuan kelas eksperimen dan kontrol dalam penelitian iniditentukan secara langsung oleh guru mata pelajaran matematika sehingga diperoleh kelas $\mathrm{VIII}_{3}$ sebagai kelas kontrol yang diajar dengan model pembelajaran konvensional dan kelas $\mathrm{VIII}_{4}$ sebagai kelas eksperimen yang diaajar dengan model pembelajaran kooperatif tipe TPS.

Variabel dalam penelitian ini terdiri dari variabel bebas yaitu perlakuan berupa pembelajaran dengan menggunakan model pembelajaran kooperatif tipe TPS pada kelas eksperimen dan perlakuan berupa model pembelajaran konseptual (konvensional) pada kelas kontrol dan variabel terikat yaitu menggunakan model pembelajaran kooperatif tipe TPS dan hasil belajar matematika siswa yang diajar dengan menggunakan model pembelajaran konvensional.

Instrumen yang digunakan di dalam penelitian ini terdiri atas dua, yakni tes hasil belajar matematika dan lembar pengamatan/observasi untuk guru dan siswa.

Tes hasil belajar matematika pada materi lingkaran dibuat berupa tes esai. Sebelum tes digunakan dalam penelitian ini, terlebih dahulu dilakukan uji coba untuk mengetahui validitas dan reliabilitas tes.

Untuk mengetahui validitas item tes digunakan korelasi Product-Moment sebagai berikut:

$\mathrm{r}_{\mathrm{xy}}=\frac{\boldsymbol{N} \sum \boldsymbol{X} \boldsymbol{Y}-\left(\sum \boldsymbol{X}\right)\left(\sum \boldsymbol{Y}\right)}{\sqrt{\left\{\boldsymbol{N} \sum \boldsymbol{X}^{2}-\left(\sum \boldsymbol{X}\right)^{2}\right\}\left\{\boldsymbol{N} \sum \boldsymbol{Y}^{2}-\left(\sum \boldsymbol{Y}\right)^{2}\right\}}}$

(Sugiyono, $2015: 228)$

Keterangan :

$\mathrm{R}_{\mathrm{xy}}=$ Koefisien korelasi antara variabel $\mathrm{x}$ dengan variabel y

$\mathrm{N}$ = Jumlah subyek

$\mathrm{X}=$ Jumlah skor item

$\mathrm{Y}=$ Jumlah skor total

Adapun kriteria pengujian yang digunakan untuk mengetahui butir soal yang valid atau tidak valid adalah sebagai berikut:

a. Jika $r \geq r_{\text {tabel }}$ dengan $\alpha=0.05$ maka item tersebut valid.

b. Jika $r<r_{\text {tabel }}$ dengan $\alpha=0.05$ maka item tersebut tidak valid.

Selanjutnya, untuk mengetahui reliabilitas tes instrumen digunakan rumus Alfa Cronbach sebagai berikut:

Keterangan:

$$
\mathrm{r}_{11}=\left(\frac{k}{k-1}\right)(\mathrm{Jihad}, 2008: 180)
$$

$\mathrm{r}_{11}=$ Nilai reliabilitas tes

$\mathrm{K}$ = Jumlah item 
$\sum \mathrm{S}_{\mathrm{i}}^{2}=$ Jumlah varians item

$\sum_{\mathrm{t}}^{2}=$ Varians total

Untuk memberikan interprestasi terhadap

koefisien reliabilitas tes $r_{11}$ digunakan patokan:

$\mathrm{R}_{11} \leq 0,20 \quad$ reliabilitas : sangat

rendah

$\begin{array}{ll}0,20<\mathrm{r}_{11} \leq 0,40 & \text { reliabilitas : rendah } \\ 0,40<\mathrm{r}_{11} \leq 0,70 & \text { reliabilitas : sedang } \\ 0,70<\mathrm{r}_{11} \leq 0,90 & \text { reliabilitas : tinggi }\end{array}$

$0,90<\mathrm{r}_{11} \leq 1,00$ reliabilitas $\quad$ sangat tinggi (Jihad, 2008: 181)

Pengambilan data dalam penelitian ini dilakukan dengan pemberian lembar observasi dan tes hasil belajar matematika. Observasi dilakukan, pada setiap pertemuan yaitu lima kali pertemuan proses pembelajaran dengan menggunakan pembelajaran TPS dan pembelajaran konvensional. Hasil observasi digunakan untuk mengetahui data mengenal aktivitas guru dan siswa. Pemberian tes hasil belajar matematika dilakukan sebanyak satu kali, yaitu setelah diberi perlakuan. Setelah kegiatan pembelajaran pada kelas eksperimen dengan model pembelajaran TPS dan pada kelas kontrol dengan pembelajaran konvensional dilaksanakan, maka dilakukan tes pada kedua kelas tersebut. Kemudian tes tersebut dikerjakan oleh siswa. Selanjutnya hasil pekerjaan siswa dikumpulkan oleh peneliti untuk diperiksa dan diberi nilai. Nilai dari hasil pekerjaan siswa inilah yang dijadikan data dalam penelitian ini.

Analisis deskriptif digunakan untuk mendeskripsikan data penelitian yang berupa perolehan skor rata-rata (x), median (Me), modus (Mo), nilai maksimum $\left(\mathrm{x}_{\max }\right)$, nilai minimum $\left(\mathrm{x}_{\min }\right)$, standar deviasi $(\mathrm{s})$ dan data varians $\left(\mathrm{s}^{2}\right)$.

Analisis inferensial dimaksudkan untuk menguji hipotesis. Namun sebelum melakukan uji hipotesis terlebih dahulu melalui tahapan uji yang lain, yaitu uji normalitas dan uji homogenitas sebagai uji prasyarat untuk melakukan uji hipotesis. Data yang digunakan dalam uji normalitas, uji homogenitas dan uji hipotesis berbentuk skor hasil belajar matematika siswa.

Uji normalitas data dimaksudkan untuk mengetahui apakah data yang diperoleh berasal dari populasi yang berdistribusi normal atau tidak. Untuk keperluan ini maka statistik yang digunakan adalah uji kolmogrov-smirnovyang dihitung dengan menggunakan program SPSS Version 16, dengan melihat nilai Asymp. Sig. (2-tailed) untuk setiap kelas $>\alpha$ (dengan $\alpha=$ 0,05), dikatakan $\mathrm{H}_{0}$ diterima.

Adapun langkah-langkah yang diperlukan dalam pengujian ini adalah sebagai berikut:

1. Menginput data hasil belajar matematika siswa pada spreadsheet data view SPSS.

2. Klik Analyze kemudian pilih Non Parametrik Test, lalu pilih Legacy Dialogs, kemudian 1Sample K.S.

3. Pindahkan variabel kelas Eksperimen dan kelas Kontrol ke Test Variable List.

4. Klik $O K$. pada langkah ini uji normalitas sudah selesai, selanjutnya adalah penentuan keputusan.

5. Jika nilai sig di atas 0,05 maka data berdistribusi normal, jika nilai sig di bawah 0,05 maka data tidak berdistribusi normal.

Uji homogenitas data dimaksudkan untuk mengetahui apakah varians data kedua kelompok yang diteliti mempunyai varians yang homogen atau tidak. Dalam penelitian ini untuk menguji apakah data mempunyai varians yang sama atau tidak digunakan statistik uji Levene dengan menggunakan program SPSS dengan kriteria pengambilan keputusan sebagai berikut:

1) Jika nilai Sig. $>\alpha=0,05$ berarti kedua kelompok memiliki varians yang homogen.

2) Jika nilai Sig. $\leq \alpha=0,05$ berarti kedua kelompok memiliki varians yang tidak homogen.

Uji normalitas dan uji homogenitas data hasil belajar matematika siswa pada kelas eksperimen dan kontrol telah dilakukan, maka dilakukanlah pengujian hipotesis. Untuk mengetahui pengaruh penggunaan model pembelajaran kooperatif tipe TPS terhadap hasil belajar matematika siswa, digunakan uji One Sample t-test. Langkah langkah pengujiannya dengan SPSS16 yaitu sebagai berikut :

1. Menginput data hasil belajar matematika siswapada spreadsheet data view SPSS.

2. Pilih analyze kemudian pilih compare means lalu pilih One Sample T Test.

3. Pada kotak dialog One sample $T$ Test. Masukkan variabel kelas eksperimen dan kelas kontrol ke dalam kotak Test Variable(s). Masukkan angka 22,65 untuk kelas eksperimen dan 21,92 untuk kelas kontrol ke kotak Test Value. 
4. Klik Options sehingga muncul kotak dialog One Sample T Test, option. Masukkan tingkat kepercayaan $95 \%$ pada kotak convidence interval percentage, lalu klik Continue. Lalu $O K$.

5. Sampai langkah ini pengujian menggunakan One Sample T Test sudah selesai, selanjutnya tinggal menentukan keputusan.

Kriteria pengambilan keputusan adalah jika nilai sig lebih kecil 0,05 maka ada pengaruh yang signifikan penggunaan model pembelajaran kooperatif tipe TPSterhadap hasil belajar matematika siswa. Jika nilai sig lebih besar dari 0,05 maka ada pengaruh yang tidak signifikan penggunaan model pembelajaran kooperatif tipe TPS terhadap hasil belajar matematika siswa.

Untuk mengetahui perbedaan pengaruh penggunaan model pembelajaran kooperatif tipe TPS dan model pembelajaran konvensionalterhadap peningkatan hasil belajar matematika siswa, digunakan uji t sampel independen. Langkah langkah pengujiannya adalah sebagai berikut :

1. Memasukkan data ke data editor dengan mendefinisikan variabel pada variabel view. Variabel 1 definisikan sebagai data hasil belajar siswa dan variabel 2 definisikan sebagai kelompok.

2. Pada bagian value labels, definisikan kelompok 1 sebagai kelas eksperimen dan kelompok 2 sebagai kelas kontrol.

3. Pilih menu analyze kemudian pilih compare means lalu pilih independent sample t test.

4. Akan tampak kotak dialog independent sample $T$ test. Masukkan variabel hasil belajar siswake kotak Test Variable(s) dan variabel kelompok ke kotak Grouping Variables.

5. Klik Define Groups akan muncul kotak dialog define groups. Masukkan kode 1 untuk group 1 dan kode 2 untuk group 2. Lalu klik continue.

6. Berikutnya akan muncul lagi kotak dialog independent - samples T test : option. Klik options, sehingga muncul kotak dialog options. Karena menggunakan alfa 0,05 maka tingkat kepercayaan yang digunakan adalah $95 \%$. Klik continue lalu $O K$.
Kriteria pengambilan keputusan adalah jika nilai sign lebih kecil dari 0,05 maka terdapat perbedaan rata-rata peningkatan hasil belajar matematika antara siswa yang mengikuti pembelajaran dengan menggunakan pembelajaran kooperatif tipe TPS dengan siswa yang mengikuti pembelajaran dengan menggunakan pembelajaran konvensional.

\section{Hasil}

Berdasarkan hasil observasi terhadap pelaksanaan pembelajaran matematika dengan menggunakan model pembelajaran kooperatif tipe Think Pair Share oleh guru di kelas eksperimen pada materi lingkaran, keberhasilan pengelolaan pembelajaran pada 5 pertemuan sudah baik. Tingkat keberhasilan secara berturut turut sebesar $100 \%, 98,99 \%, 81,25 \%, 90,63$ dan 93,75\%.

Berdasarkan hasil observasi aktivitas siswa dalam pelaksanaan pembelajaran matematika menggunakan model pembelajaraan kooperatif tipe Think Pair Share di kelas eksperimen pada materi lingkaran pada 5 pertemuan, ketercapaian seluruh aspek yang diamati adalah 65,73\%, 68,75\%, 72,92\%, $83,33 \%$ dan $87,5 \%$. Persentase ini menunjukkan tidak pada setiap pertemuan siswa mampu mengkondisikan diri maupun kelompoknya untuk dapat melaksanakan proses pembelajaran dengan model pembelajaran kooperatif tipe Think Pair Share secara maksimal.

Ukuran statistik data diperoleh dari analisis data hasil tes kemampuan hasil belajar matematika siswa yang dilaksanakan terhadap kelas eksperimen dan kelas kontrol. Penentuan kelas eksperimen dan kelas kontrol dilakukan secara purposive sampling seperti yang telah dikemukakan pada bab III. Kelas eskperimen yaitu kelas $\mathrm{VIII}_{4}$ dengan jumlah siswa 31 orang, dan kelas kontrol yaitu kelas $\mathrm{VIII}_{3}$ dengan jumlah siswa 30 orang.

Ukuran statistik data diperoleh dari analisis data posttest kemampuan hasil belajar matematika siswa yang dilaksanakan terhadap kelas eksperimen. Analisis deskriptif dengan menggunakan bantuan Microsoft Excel diperoleh data hasil belajar matematika siswa pada tabel 1 . 


\section{Tabel 1}

\section{Statistik Deskripsi Terhadap Hasil Belajar Matematika Siswa Kelas Eksperimen}

\begin{tabular}{|l|l|l|}
\hline \multirow{2}{*}{ Statistik } & \multicolumn{2}{|l|}{ Hasil Belajar Matematika Siswa } \\
\cline { 2 - 3 } & K-Eksperimen & \multicolumn{1}{c|}{ K-Kontrol } \\
\hline Mean & 55,43 & 31,80 \\
\hline Varians $\left(\mathrm{S}^{2}\right)$ & 457,44 & 161,60 \\
\hline SD & 21,39 & 12,71 \\
\hline Max & 88,46 & 61,53 \\
\hline Min & 19,23 & 11,53 \\
\hline Median & 57,69 & 30,76 \\
\hline Modus & 73,07 & 34,61 \\
\hline $\mathrm{N}$ & 30 & 26 \\
\hline
\end{tabular}

Hasil analisis deskriptif pada kelas eksperimen sebagaimana disajikan pada tabel di atas diperoleh nilai terendah 25 dan nilai tertinggi 75 , nilai rata-rata 55,43 , median atau nilai tengah 57,69 , modus atau nilai yang sering muncul yaitu 73 , standar deviasi 21,39 dan varians 457,44 .
Uji normalitas data pada kelas eksperimen dalam penelitian ini menggunakan statistik uji Kolmogorov-Smirnov menggunakan bantuan program SPSS,hasil perhitungannya disajikan dalam Tabel 2.

Tabel 2

Hasil Analisis Statistik Uji Normalitas Data TerhadapHasilBelajarMatematika Siswa pada Kelas Eksperimen

One-Sample Kolmogorov-Smirnov Test

\begin{tabular}{|c|c|}
\hline & K_Eksperimen \\
\hline $\mathrm{N}$ & 30 \\
\hline Normal parameters ${ }^{\mathrm{a}}$ & 1.4667 \\
\hline Std. Deviation & .73030 \\
\hline Most Extreme Differences & .367 \\
\hline Positive & .233 \\
\hline Negative & -.367 \\
\hline Kolmogorov-Smirnov Z & 2.012 \\
\hline Asymp. Sig. (2-tailed) & .001 \\
\hline
\end{tabular}

a. Test distribution is normal.

Berdasarkan Tabel 4.6 di atas dapat dilihat bahwa nilai Asymp.Sig. (2-tailed) untuk hasil perhitungan uji normalitas dengan menggunakan statistik uji Kolmogorov-Smirnov pada kelas eksperimen diperoleh $0,001<0,05$ sehingga $\mathrm{H}_{0}$ diterima. Dengan demikian dapat disimpulkan b ahwa data nilai hasil belajar matematika siswa $\mathrm{d}$ engan menggunakan model pembelajaran kooperatif tipe TPS berdistribusi normal. Uji normalitas data pada kelas kontrol dalam penelitian ini menggunakan statistik uji Kolmogorov-Smirnov menggunakan bantuan program SPSS 16, hasil perhitungannya disajikan dalam Tabel 3. 
Tabel 3

\author{
Hasil Analisis Statistik Uji Normalitas Data \\ Hasil Belajar Matematika Siswa pada Kelas Kontrol
}

One-Sample-Kolmogorov-Smirnov Test

\begin{tabular}{|c|c|}
\hline & K_Kontrol \\
\hline $\mathrm{N}$ & 26 \\
\hline Normal parameters $^{\mathrm{a}}$ & .5769 \\
\hline Std. Deviation & .85665 \\
\hline Most Extreme Differences $\quad$ Absolute & .404 \\
\hline Positive & .404 \\
\hline Negative & -.250 \\
\hline Kolmogorov-Smirnov Z & 2.058 \\
\hline Asymp. Sig. (2-tailed) & .000 \\
\hline
\end{tabular}

a. Test distribution is normal

BerdasarkanTabel 4.7 di atas dapat dilihat bahwa nilai Asymp.sig.(2tailed) untuk hasil perhitungan uji normalitas dengan menggunakan statistik uji kolmogorov-smirnov pada kelas kontrol diperoleh 0,000>0,05 sehingga $\mathrm{H}_{0}$ diterima. Dengan demikian dapat disimpulkan bahwa data nilai hasil belajar matematika siswa dengan menggunakan model pembelajaran konvensional berdistribusi normal.

Uji normalitas digunakan untuk mengetahui apakah data kemampuan hasil belajar matematika siswa kedua kelas berdistribusi normal atau tidak. Untuk menguji apakah data berdistribusi normal atau tidak digunakan statistik uji normalitas dengan uji Kolmogorov-Smirnov, menggunakan bantuan program SPSS. Hasil perhitungannya bahwa nilai Asym.Sig.(2-tailed) diperoleh 0,001 <0,05 sehingga $\mathrm{H}_{0}$ diterima. Data pada kelas eksperimen berdistribusi normal. Data pada kelas kontrol juga berdistribusi normal. Dengan demikian, dapat disimpulkan bahwa sebaran data hasil belajar matematika siswa pada kedua kelas berdistribusi normal.

Uji homogenitas digunakan untuk mengetahui apakah data mempunyai varians yang sama (homogen) atau tidak. Untuk menguji apakah data mempunyai varians yang sama atau tidak Untuk menguji apakah data mempunyai varians yang sama atau tidak digunakan statistik uji $\mathrm{F}$ dengan menggunakan program microsoft excel seperti yang terlihat bahwa nilai dari $\mathrm{F}_{\text {hitung }}$

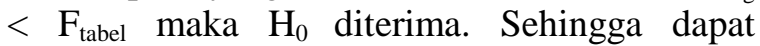
disimpulkan bahwa kedua kelompok memiliki varians yang relatif sama. Ini berarti sebaran kedua kelompok yaitu yang mendapat model pembelajaraan kooperatif tipe Think Pair Share dan model pembelajaran konvensional memiliki varians homogen. Data yang diperoleh berdistribusi normal, dan memiliki varians yang homogen, maka untuk menguji tes hasil belajar matematika siswa yang diajar dengan menggunakan model pembelajaran kooperatif tipe Think Pair Share dan siswa yang diajar dengan model pembelajaran konvensional, digunakan uji one sample t test. Rumus hipotesis statistik yang diuji adalah :

Keterangan :

$$
\mathrm{H}_{0}: \mu_{1} \leq \mu_{2} \text { lawan } \mathrm{H}_{1}: \mu_{1}>\mu_{2}
$$

$\mathrm{H}_{0}=$ Pengaruh pembelajaran kooperatif tipe TPS sama dengan model pendekatan pembelajaran konvensional terhadap hasil belajar matematika siswa.

$\mathrm{H}_{1}=$ Pengarauh pembelajaran kooperatif tipe TPS lebih baik dibandingkan dengan pendekatan konvensional terhadap hasil belajar matematika siswa.

$\mu_{1}=$ Rerata hasil belajar matematika siswa yang diajar dengan menggunakan pembelajaran kooperatif tipe TPS.

$\mu_{2}=$ Rerata hasil belajar matematika siswa yang diajar dengan menggunakan pembelajaran konvensional.

digunakan statistik uji leneves eperti yang disajikan pada tabel 4 . 
Tabel 4

Hasil Uji Homogenitas Data Hasil Belajar Matematika Siswa pada Kelas Eksperimen dan Kelas Kontrol Test of Homogeneity of Variances

VAR00001
\begin{tabular}{|l|l|l|l|}
\hline Levene Statistic & df1 & df2 & Sig. \\
\hline 1.791 & 4 & 20 & .170 \\
\hline
\end{tabular}

Berdasarkan Tabel 4.8 di atas dapat dili hat bahwa nilai signifikasi statistik uji leneve adalah

0,00 . Nilai signifikan ini lebih besar dari taraf si gnifikasi 0,05 (nilai sig. $(0,170)>0,05)$, maka $\mathrm{H}$ ${ }_{0}$ diterima. Sehingga dapat disimpulkan bahwa kelas eksperimen dan kelas kontrol memiliki varians yang sama. Ini berarti data yang diperoleh dari perlakuan dengan model pembelajaran kooperatif tipe TPS dan model pembelajaran konvensional memiliki varians yang sama (homogen).

Hasil uji normalitas dan uji homogenitas menunjukan bahwa data hasil belajar matematika

siswa kelas eksperimen dan kelas kontrol berdist ribusi normal dan homogen. Selanjutnya dilakuk an uji hipotesis masing-masing kelas untuk mengetahui pengaruh model pembelajaran kooperatif tipe TPS dan model pembelajaran langsung terhadap hasil belajar matematika siswa digunakan rumus uji-t satu sampel (OneSample Test). Rumusan hipotesis statistik yang diuji adalah:

$\mathrm{H}_{0}: \mu_{1} \leq \mu_{2}$

$\mathrm{H}_{1}: \mu_{1}>\mu_{2}$

Keterangan:

$\mu_{1}=$ rerata hasil belajar matematika siswa pada kelas yang diajar dengan model pembelajaran kooperatif tipe TPS.

$\mu_{2}=$ rerata hasil belajar matematika siswa pada kelas yang diajar dengan model pembelajaran konvensional.

Hipotesis yang diajukan :

$\mathrm{H}_{0}=$ Tidak terdapat pengaruh yang signifikan model pembelajaran kooperatif tipe TPS terhadap peningkatan hasil belajar matematika siswa.

$\mathrm{H}_{1}=$ Terdapat pengaruh yang signifikan model pembelajaran kooperatif tipe TPS terhadap peningkatan hasil belajar matematika siswa.

Untuk menguji signifikansi pengaruh model pembelajaran kooperatif tipe TPS terhadap hasil belajar matematika siswa pada kelas eksperimen, digunakan uji one sample $t$ test. Hasil pengujiannya dapat dilihat pada Tabel 5.

Tabel 5

Hasil Analisis Statistik Uji Hipotesis Hasil Belajar Matematika Siswa pada Kelas Eksperimen

One-Sample Test

\begin{tabular}{|c|c|c|c|c|c|c|}
\hline & \multicolumn{6}{|c|}{ Test Value $=22,65$} \\
\hline & \multirow[b]{2}{*}{$\mathrm{T}$} & \multirow[b]{2}{*}{ Df } & \multirow[b]{2}{*}{ Sig. (2-tailed) } & \multicolumn{3}{|c|}{$\begin{array}{l}\text { 95\% Confidence Interval of the } \\
\text { Difference }\end{array}$} \\
\hline & & & & $\begin{array}{l}\text { Mean } \\
\text { Difference }\end{array}$ & Lower & Upper \\
\hline VAR00001 & -158.875 & 29 & .000 & -21.18333 & -21.4560 & \begin{tabular}{|l|}
-20.9106 \\
\end{tabular} \\
\hline
\end{tabular}

Berdasarkan Tabel 4.9 di atas, terlihat bahwa nilai sig. (2-tailed) lebih kecil dari $\alpha=0,05 \quad$ (sig. $2-$ tailed $=0,000<0,05$ ), sehingga $\mathrm{H}_{0}$ ditolak. Karena $\mathrm{H}_{0}$ ditolak, maka dapat disimpulkan bahwa terdapat pengaruh yang signifikan penggunaan model pembelajaran kooperatif tipe TPS pada kelas eksperimen terhadap hasil belajar matematika siswa SMP Negeri 8 Kendari pada materi lingkaran.

Untuk menguji signifikansi pengaruh model pembelajaran konvensional terhadap hasil belajar matematika siswa pada kelas kontrol, digunakan uji one sample $t$ test. Hasil pengujiannya dapat dilihat pada Tabel 6 . 
Tabel 6

Hasil Analisis Statistik Uji Hipotesis Hasil Belajar Matematika Siswa pada Kelas Kontrol

One-Sample Test

\begin{tabular}{|c|c|c|c|c|c|c|}
\hline & \multicolumn{6}{|c|}{ Test Value $=22,65$} \\
\hline & \multirow[b]{2}{*}{$\mathrm{T}$} & \multirow[b]{2}{*}{ Df } & \multirow[b]{2}{*}{ Sig. (2-tailed) } & \multicolumn{3}{|c|}{$\begin{array}{l}\text { 95\% Confidence Interval of the } \\
\text { Difference }\end{array}$} \\
\hline & & & & $\begin{array}{l}\text { Mean } \\
\text { Difference }\end{array}$ & Lower & Upper \\
\hline VAR00001 & -127.040 & 25 & .000 & -21.34308 & -21.6891 & -20.9971 \\
\hline
\end{tabular}

Berdasarkan Tabel 4.10 di atas, terlihat bahwa nilai setengah sig. (2-tailed) lebih kecil dari $\alpha=0,05$ (sig. $2-$ tailed $=$ $0,000<0,05)$, sehingga $\mathrm{H}_{0}$ ditolak. Karena $\mathrm{H}_{0}$ ditolak, maka dapat disimpulkan bahwa terdapat pengaruh yang signifikan penggunaan model pembelajaran konvensional pada kelas kontrol terhadap hasil belajar matematika siswa SMP Negeri 8 Kendari pada materi lingkaran.

Untuk mengetahui perbedaan pengaruh penggunaan model pembelajaran kooperatif tipe TPS dan model pembelajaran konvensional terhadap peningkatan hasilbelajarmatematika siswa, digunakan uji $\mathrm{T}$ sample independen. Uji ini digunakan untuk mengetahui ada atau tidaknya perbedaan pengaruh penggunaan model pembelajaran kooperatif tipe TPS dan model pembelajaran konvensional terhadap peningkatan hasil belajar matematika siswa. Rumus hipotesis statistik yang diuji adalah :

$\mathrm{H}_{0}: \mu_{1} \leq \mu_{2}$ lawan $\mathrm{H}_{1}: \mu_{1}>\mu_{2}$

Keterangan:

$\mu_{1}=$ rerata hasil belajar matematika siswa pada kelas yang diajar dengan model pembelajaran kooperatif tipe TPS.

$\mu_{2}=$ rerata hasil belajar matematika siswa pada kelas yang diajar dengan model pembelajaran konvensional.

Hasil pengujiannya dapat dilihat pada Tabel 7.

Tabel 1.7

\section{Hasil Uji T Sampel Independen Independent Samples Test}

\begin{tabular}{|l|l|l|l|l|l|l|}
\hline & $\begin{array}{l}\text { Leven } \\
\text { e's } \\
\text { Test } \\
\text { for } \\
\text { Equal } \\
\text { ity of } \\
\text { Varia } \\
\text { nces }\end{array}$ \\
\hline
\end{tabular}


terhadap peningkatan hasil belajar matematika siswa SMP Negeri 8 Kendari.

\section{Pembahasan}

Jenis penelitian ini adalah penelitian eksperimen semua dengan desain posttest control group tentang pengaruh model pembelajaran kooperatif tipe TPS terhadap hasil belajar matematika siswa kelas VIII SMPN 8 Kendari. Data hasil belajar matematika siswa diperoleh melalui tes hasil belajar matematika siswa.Sebelum siswa diberikan perlakuan yaitu pembelajaran dengan model pembelajaran kooperatif tipe TPS, tes diberikan pada materi pembelajaran pada kelas VIII semester 2 sistem persamaan linear dua variabel.Tes yang diberikan setelah adanya perlakuan yaitu tes pada materi lingkaran.

Dalam penelitian ini menggunakan dua kelas sebagai kelas eksperimen dan kelas kontrol. Kelas eksperimen mengunakan model pembelajaran kooperatif tipe TPS, sedangkan kelas kontrol menggunakan model pembelajaran konvensional. Pada kedua kelas, siswa diberi pretest sebelum proses pembelajaran dilaksanakan, kemudian diberi posttest setelah pembelajaran selesai dilaksanakan.

Total pertemuan dalam penelitian ini yaitu sebanyak lima kali pertemuan digunakan untuk proses pembelajaran, ditambah dua kali pertemuan digunakan untuk tes hasil belajar matematika siswa yakni, pretest dan posttest pada masing-masing kelas. Selain itu, kedua kelas juga diberi materi yang sama dengan urutan yang sama. Pembelajaran yang dilaksanakan pada kelas eksperimen adalah model pembelajaran kooperatif tipe TPS, yang memiliki empat tahap pembelajaran yaitu menyampaikan tujuan dan memotivasi siswa, menyampaikan informasi, mengorganisasikan siswa ke dalam kelompok belajar, membimbing kelompok bekerja dan belajar, evaluasi, serta memberikan penghargaan.

Pada tahap menyampaikan tujuan dan memotivasi siswa, merupakan tahap menyampaikan semua tujuan yang dicapai pada pelajaran tersebut dan memotivasi siswa belajar. Pada tahap menyampaikan informasi, merupakan menyajikan informasi kepada siswa dengan jalan demonstrasi atau lewat bahan bacaan.

Tahap mengorganisasikan siswa ke dalam kelompok belajar merupakan tahap mengelompokan siswa sebanyak 6 orang tiap kelompok dan anggota setiap kelompok harus heterogen baik dari segi hasil belajar, jenis kelamin, agama, suku dan sebagainya. Tahap membimbing kelompok bekerja dan belajar bertujuan agar siswa dapat belajar dan berinteraksi dengan temannya sesuai kondisi kelas tersebut, khususnya pada materi lingkaran. Pada tahap ini dalam pembelajarannya,guru membantu siswa jika siswa kesulitan dalam mengerjakan soal, yaitu siswa secara berkelompok berdiskusi mengerjakan lembar kegiatan siswa (LKS) dan memberikan kesempatan kepada siswa untuk menemukan berbagai cara penyelesaian dari masalah yang diberikan. Pada tahap ini terjadi diskusi antar siswa dalam kelompok. Pada tahap ini, seluruh indikator hasilbelajardapat dikembangkan melalui soal-soal yang diberikan. Dalam tahap membimbing kelompok belajar, guru memperhatikan diskusi yang sedang berlangsung dalam tiap kelompok, serta bertindak sebagai fasilitator. Artinya, jika siswa merasa kesulitan dalam kegiatan menemukan kemungkinan-kemungkinan cara penyelesaian dan mendorong siswa tersebut mengumpulkan informasi untuk mendapatkan pemecahan masalah.

Selanjutnya, pada tahap evaluasi, guru mengevaluasi hasil belajar tentang materi yang telah dipelajari atau masing-masing kelompok mempersentasekan hasil kerjanya Sedangkan pada tahap memberikan penghargaan, guru memberikan penghargaan atas hasil kerja siswa dalam kelompok.

Pada pertemuan di kelas eksperimen pertamatama dilakukan kegiatan, yang meliputi mengondisikan kelas dan menyampaikan tujuan pembelajaran dan penyampaian tujuan pembelajaran, kemudian dilakukan pembagian kelompok yang heterogen. Dalam proses pembelajaran di kelas ini, siswa dibagi menjadi 5 kelompok dengan tiap kelompok beranggotakan 6 orang siswa. Kemudian pada setiap siswa diberikan bahan ajar dan LKS untuk dikerjakan secara berkelompok. Pada tahap ini, siswa diberikan pengarahan dan bimbingan melalui penjelasan atau pertanyaan yang mengarah pada penyelesaian masalah bila diminta langsung oleh siswa. Setelah semua kelompok telah mengerjakan LKS yang diberikan sesuai dengan waktu yang ditetapkan, beberapa siswa dipilih mewakili kelompoknya tampil di depan kelas untuk mempresentasekan 
hasil kerja kelompoknya untuk ditanggapi oleh kelompok lain. Jika ada jawaban siswa yang keliru maka diberikan bantuan untuk mengambil kesimpulan alternatif jawaban yang benar dari hasil pemecahan masalah yang dibuat masingmasing kelompok. Diakhir pertemuan, siswa membuat kesimpulan dari materi yang telah dipelajari. Kemudian diberikan tes evaluasi berupa lembar penilaian (LP) yang dikerjakan secara individu dan ditutup dengan pemberian tugas yang dikerjakan di rumah.

Pada awal pelaksanaan perlakuan pada kelompok eksperimen mengalami sedikit hambatan. Siswa membutuhkan waktu untuk menyesuaikan diri dengan model pembelajaran yang baru diterapkan di kelas, terutama pada saat pembentukan kelompok, sehingga proses ini cukup menyita waktu pembelajaran. Siswa yang tidak terbiasa dengan pembentukkan kelompok belajar, awalnya kurang antusias dalam proses pembelajaran ini. Beberapa siswa menunjukkan sikap yang kurang bekerjasama dalam kelompok, sehingga tidak semua siswa aktif dalam kelompok belajar pada saat proses pembelajaran berlangsung. Hal ini mengakibatkan proses penyerapan materi pembelajaran oleh siswa kurang maksimal.

Pada pertemuan kedua dan pertemuanpertemuan selanjutnya, proses pembelajaran dapat berjalan dengan cukup baik dan lancar. Meskipun khusus pada pertemuan ketiga, proses pelaksanaan pembelajaran dengan model pembelajaran kooperatif tipe TPS tidak maksimal, karena peneliti kurang memotivasi siswa. Beberapa siswa juga masih mengalami kesulitan dalam menggali dan mengolah informasi dari LKS dan sumber belajar lainnya, sehingga siswa tersebut belum mampu menemukan sendiri penyelesaian dari masalah yang diberikan. Namun dengan arahan dan bimbingan, siswa sudah mulai mengerti dengan model pembelajaran kooperatif tipe TPS.

Siswa sudah menunjukkan sikap yang antusias dalam proses pembelajaran dan mulai merasa bertanggung jawab dalam kelompok belajarnya, untuk mengerjakan tugas-tugas kelompok. Selain itu, siswa diberikan umpan balik terhadap respon-respon yang dimilikinya dan mendorong siswa megumpulkan informasi untuk mendapatkan solusi dari masalah yang diberikan. Sehingga dapat disimpulkan bahwa, siswa juga memerlukan waktu untuk beradaptasi terhadap suatu pembelajaran yang baru diterapkan. Ini juga terlihat dari persentase ketercapaian aspek yang diamati, walaupun peningkatannya tidak tinggi, namun secara keseluruhan, presentase ketercapaian pembelajaran ini cukup mengalami peningkatan tiap pertemuan.

Data hasil belajar matematika siswa diperoleh melalui tes hasil belajar matematika siswa. Tes tersebut diberikan kepada siswa kelas eksperimen dan kelas kontrol. Pada kelas eksperimen diperoleh nilai rata-rata hasil belajar 55,43 yang tergolong rendah dan standar deviasi sebesar 21,39 yang menunjukkan bahwa besar penyimpangan data dari rata-rata kelas cukup rendah, ini bisa menginterpretasikan bahwa pembelajaran yang berlangsung cukup merata ke semua siswa. Pembelajaran yang berlangsung merata ke semua siswa disebabkan dipembelajaran ini dilakukan pembagian kelompok yang heterogen yang dapat mendorong siswa untuk mampu membangun pengetahuan secara bersama-sama di dalam kelompok dan menafsirkan bersama-sama apa yang mereka temukan atau mereka bahas. Dengan demikian sesuai dengan teori belajar konstruktivisme siswa didorong untuk memunculkan berbagai sudut pandang terhadap materi atau masalah yang sama, untuk kemudian membangun sudut pandang atau mengkonstruksi pengetahuannya secara bersama-sama.

Sedangkan pada kelas kontrol diperoleh nilai rata-rata hasil belajar 31,80 yang tergolong rendah. Standar deviasi pada kelas kontrol lebih besar dari kelas eksperimen yaitu sebesar 12,71, ini juga bisa menginterprestasikan bahwa pembelajaran yang konvensional cukup merata ke semua siswa. Penyebab penyimpangan dari nilai rata rata pada kelas kontrol yang lebih besar daripada kelas eksperimen ini salah satunya adalah karena proses pembelajaran pada kelas kontrol lebih teacher centered.

Untuk mengetahui pengaruh penggunaan model pembelajaran kooperatif tipe TPS terhadap hasil belajar matematika siswa, dilakukan uji hipotesis rata-rata hasil belajar matematika siswa pada kedua kelas dengan menggunakan statistik independent sample $t$ test. Dengan terlebih dahulu melewati uji prasyarat yaitu uji normalitas data kelas eksperimen dan kelas kontrol serta uji homogenitas varians data kedua kelompok sampel. Berdasarkan uji normalitas data dengan menggunakan uji Kolmogorov-Smirnov 
diperoleh untuk data hasil belajar matematika siswa kelas eksperimen dan kelas kontrol berdistribusi normal. Selanjutnya, berdasarkan hasil uji homogenitas varians data hasil belajar matematika siswa kelas eksperimen dan kelas kontrol menggunakan uji $\mathrm{F}$, diperoleh bahwa data hasil belajar matematika kedua kelompok mempunyai varians yang homogen.

Berdasarkan hasil uji hipotesis untuk melihat perbedaan pengaruh penggunaan model pembelajaran kooperatif tipe TPS dan pembelajaran konvensional terhadap peningkatan hasil belajar matematika siswa, diperoleh bahwa terdapat perbedaan pengaruh yang signifikan penggunaan model pembelajaran kooperatif tipe TPS dan pembelajaran konvensional terhadap peningkatan hasil belajar matematiaka siswa. Hal ini didasarkan pada nilai signifikansi independent sample t-test lebih besar dari 0,05 yang berarti $\mathrm{H}_{0}$ diterima. Dengan kata lain,tidakterdapat perbedaan pengaruh yang signifikan penggunaan model pembelajaran kooperatif tipe TPS dan pembelajaran konvensional terhadap peningkatan hasil belajar matematika siswa.

\section{Simpulan dan Saran}

\section{Simpulan}

Berdasarkan hasil penelitian dan pembahasan, maka dapat ditarik beberapa kesimpulan, yaitu sebagai berikut :

1. Hasil belajar matematika siswa yang mengikuti pembelajaran dengan menggunakan model pembelajaran kooperatif tipe TPS pada awalnya rendah. Setelah beberapa kali dilakukan pembelajaran kooperatif tipe TPS, hasil belajar matematika siswa memang cenderung meningkat, walaupun tidak signifikan. Ini terlihat dari rata-rata pretest sebesar 28,25 dan rata-rata posttest sebesar 55,43 sehingga diperoleh peningkatan hasil belajar matematika siswa sebesar 54,61 yang tergolong sedang.

2. Hasil belajar matematika siswa yang mengikuti pembelajaran dengan menggunakan pembelajaran rendah pada awalnya rendah. Setelah beberapa kali dilakukan proses belajar mengajar dengan pembelajaran konvensional, hasil belajar matematika siswa memang cenderung meningkat, walaupun tidak signifikan. Ini terlihat dari rata-rata pretest sebesar 23,24 dan posttest 31,80 sehingga diperoleh peningkatan hasil belajar matematika siswa sebesar 31,80 yang tergolong rendah.

3. Terdapat pengaruh yang signifikan penggunaan model pembelajaran kooperatif tipe TPS terhadap peningkatan hasil belajar matematika siswa. Hal ini didasarkan pada nilai yang lebih kecil dari 0,05 yang berarti $\mathrm{H}_{0}$ ditolak, sehingga dapat disimpulkan bahwa terdapat pengaruh yang signifikan penggunaan model pembelajaran kooperatif tipe TPS terhadap peningkatan hasil belajar matematika siswa.

\section{Saran}

Berdasarkan kesimpulan yang diperoleh dalam penelitian ini, maka peneliti memberikan saran-saran seperti berikut ini :

1. Kepada guru yang mengajar mata pelajaran matematika dapat menggunakan model pembelajaran kooperatif tipe TPS sebagai salah satu alternative pembelajaran dalam pembelajaran matematika untuk mengoptimalkan hasil belajar matematika siswa dalam pembelajaran matematika.

2. Hendaknya hasil belajar matematika siswa mendapat perhatian khusus dari pihak guru karena setiap materi yang diajarkan harus mengandung unsur pemahaman didalamnya.

3. Bagi peneliti yang hendak mengembangkan penelitian ini dapat melakukannya pada materi lain atau dengan yang memiliki kemampuan rendah untuk mengembangkan pembelajaran menggunakan model pembelajaran kooperatif tipe TPS untuk meningkatkan hasil belajar matematika siswa.

4. Bagi peneliti yang hendak menggunakan model pembelajaran kooperatif tipe TPS sebaiknya menggunakan teknik tertentu untuk memanfaatkan waktu dengan baik sehingga pembelajaran dengan menggunakan model pembelajaran kooperatif tipe TPS dapat dilaksanakan dengan maksimal.

\section{Daftar Pustaka}

Abdurrahman. (2003). Pendidikan Bagi Anak B erkesulitan Belajar. Bandung:

Rineka Cipta. 
Asmi, (2014). Pengaruh Pendekatan Saintifik Terhadap Kemampuan Berpikir Kritis Siswa Dalam Pembelajaran Matematika. ISSN: 2086-8235.Jurnal Pend.Mat Dan IPA, FKIP, UNHALU, Vol.1, No.2, Juli 2010.

Dimyanti dan Mudjiono. (2002).Belajar dan Pembelajaran.Jakarta: RinekaCipta.

Hamalik, (2010). Kurikulum dan Pembelajaran. Jakarta: PT. Bumi Aksara.

Ismail, (2000). Model-Model Pembelajaran Kooperatif. Surabaya: University Press.

Jihad dan Abdul. (2008). Evaluasi Pendidikan Yogyakarta: Multi Pressindo.
Juliantara, (2011). Pembelajaran Konvensional. Tersedia di: http://xPresiriau. Com/artikel-tulisan pendidikan/pembelajaran konvensional/.[14 November 2013].

Sudjana. (1989). Penilaian Hasil Proses Belajar Mengajar. Bandung: Remaja Rosdakarya.

Tim Penyusun Kamus Pusat Bahasa.(2008). Kamus Bahasa Indonesia. Jakarta: Pusat Bahasa.

Widyantini. (2006). Model Pembelajaran Matem atika Dengan Pendekatan Kooperatif. PPPG Matematika. Yogyakarta. [online]. Tersedia di: http://www. P4tk matematika. Org/downloads/ppp/ppp pembelajaran kooperatif pada. [15 November 2013]. 